\title{
RCAN1 in the inverse association between Alzheimer's disease and cancer
}

\author{
Qiang Fu ${ }^{1}$ and Yili Wu $\mathbf{u}^{2,3,4}$ \\ ${ }^{1}$ Department of General Surgery, Tianjin Medical University General Hospital, Tianjin, China \\ 2 Department of Psychiatry, Jining Medical University, Jining, Shandong, China \\ ${ }^{3}$ Shandong Key Laboratory of Behavioral Medicine, Jining, Shandong, China \\ ${ }^{4}$ Collaborative Innovation Center for Birth Defect Research and Transformation of Shandong Province, Jining, Shandong, \\ China. \\ Correspondence to: Yili Wu, email: yili_WU2004@yahoo.ca \\ Keywords: RCAN1; Alzheimer's disease; cancer; inverse association; Gerotarget \\ Received: June 29, $2017 \quad$ Accepted: November 17, $2017 \quad$ Published: December 11, 2017
}

Copyright: Fu et al. This is an open-access article distributed under the terms of the Creative Commons Attribution License 3.0 (CC BY 3.0), which permits unrestricted use, distribution, and reproduction in any medium, provided the original author and source are credited.

\section{ABSTRACT}

The inverse association between Alzheimer's disease (AD) and cancer has been reported in several population-based studies although both of them are agerelated disorders. However, molecular mechanisms of the inverse association remain elusive. Increased expression of regulator of calcineurin 1 (RCAN1) promotes the pathogenesis of $A D$, while it suppresses cancer growth and progression in many types of cancer. Moreover, aberrant RCAN1 expression is detected in both AD and various types of cancer. It suggests that RCAN1 may play a key role in the inverse association between AD and cancer. In this article, we aim to review the role of RCAN1 in the inverse association and discuss underlying mechanisms, providing an insight into developing a novel approach to treat $A D$ and cancer.

\section{INTRODUCTION}

Alzheimer's disease (AD) is the most common type of neurodegenerative disease leading to dementia and aging is the major risk factor of $\mathrm{AD}$ development [1-2]. Cancer is one of the leading causes of morbidity and mortality worldwide and aging is also a fundamental factor in cancer development [3]. The inverse association between $\mathrm{AD}$ and cancer has been reported in several population-based studies [4-15]. Elucidating underlying mechanisms of the inverse association between AD and cancer will be beneficial to developing effective therapy for $\mathrm{AD}$ and cancer, particularly for $\mathrm{AD}$ as there is no effective treatment for AD. Recent studies indicate that regulator of calcineurin 1 (RCAN1) may play a key role in the inverse association between $\mathrm{AD}$ and cancer. For example, RCAN1 elevation promotes AD pathogenesis, while increased RCAN1 suppresses tumor growth [16-18]. Thus, we aim to review the role of RCAN1 in the inverse association and discuss underlying mechanisms, providing potential strategies for the treatment and prevention of $A D$ and cancer by modulating RCAN1.

\section{RCAN1 GENE AND PROTEINS}

Historically, RCAN1 has been named as DSCR1, MCIP1, ADAPT78, CSP1, DSC1 and RCN1. According to its conserved function of regulating calcineurin activity and calcineurin-dependent phenotypes in various types of cells and species, it was officially renamed as regulator of calcineurin 1 in 2007 [19-44] (Table 1). The RCAN1 gene is located on chromosome 21 , consisting of seven exons and six introns. RCAN1.1 and RCAN1.4 are the two major transcripts generated by alternative mRNA splicing, composing of exon 1, 5, 6, 7 and exon 4, 5, 6, 7, respectively[45]. RCAN1.1 is highly expressed in the brain, heart and skeletal muscle, whereas RCAN1.4 is predominantly expressed in the heart and skeletal muscle. The two transcripts are mainly translated into RCAN1.1L and RCAN1.4 isoforms with 252 and 197 amino acids, respectively. In addition, the transcript RCAN1.1 can also be translated into RCAN1.1S from the downstream translational start site by leaky scanning and reinitiation mechanisms although its expression is extremely low [18]. RCAN1.1 and RCAN1.4 transcripts are differentially regulated at transcriptional level as their transcription is 
Table 1: General functions of RCAN1

\begin{tabular}{|l|l|l|l|l|}
\hline $\begin{array}{l}\text { Experimental } \\
\text { condition }\end{array}$ & $\begin{array}{l}\text { CaN interaction/ } \\
\text { activity }\end{array}$ & Cells/species & Affected phenotypes & References \\
\hline $\begin{array}{l}\text { In vitro \& } \\
\text { In vivo }\end{array}$ & + & $\begin{array}{l}\text { U2OS, COS-7, CHO, } \\
\text { PC12, HEK293 } \\
\text { Rat myocyte, } \\
\text { mouse }\end{array}$ & & {$[33,37-41]$} \\
\hline In vitro & & HA-1 & Cell proliferation & {$[42]$} \\
\hline In vivo & + & S. cerevisiae & & {$[121]$} \\
\hline $\begin{array}{l}\text { In vitro \& } \\
\text { In vivo }\end{array}$ & + & $\begin{array}{l}\text { C2C12 } \\
\text { Mouse myocyte }\end{array}$ & Cardiac hypertrophy & {$[43-44]$} \\
\hline In vitro & + & C2C12 & & {$[133]$} \\
\hline In vitro & + & $\begin{array}{l}\text { HA-1 } \\
\text { PC12 }\end{array}$ & $\begin{array}{l}\text { Cell death } \\
\text { Cell proliferation }\end{array}$ & {$[130]$} \\
\hline In vivo & + & Drosophila & Learning deficits & {$[26]$} \\
\hline $\begin{array}{l}\text { In vitro \& } \\
\text { In vivo }\end{array}$ & + & $\begin{array}{l}\text { COS-7, CHO } \\
\text { SH-SY5Y } \\
\text { Mouse brain }\end{array}$ & & {$[134]$} \\
\hline In vivo & + & C. elegans & $\begin{array}{l}\text { Calcineurin-deficient } \\
\text { phenotypes: } \\
\text { inhibition, small bowth } \\
\text { size }\end{array}$ & {$[24]$} \\
\hline $\begin{array}{l}\text { In vitro \& } \\
\text { In vivo }\end{array}$ & + & $\begin{array}{l}\text { BHK } \\
\text { Cell death }\end{array}$ & {$[135-136]$} \\
\hline In vivo & + & Mouse & Cardiac hypertrophy & {$[137]$} \\
\hline In vivo & + & Mouse & Cytokine expression & {$[138]$} \\
\hline In vitro & + & E6-1 & {$[21]$} \\
\hline
\end{tabular}

driven by differential promoters [45-46].

The interaction of RCAN1 with calcineurin $(\mathrm{CaN})$ and the role of RCAN1 in regulating calcineurin activity/ calcineuin-dependent functions are well conserved across species and cell lines, which has been well studied in multiple cell lines (e.g., COS-7, CHO, U2OS, HA-1, HEK293, SH-SY5Y, C2C12, BHK, primary neurons, HUVEC) and organisms (e. g., yeast, C. elegans, Drosophila, mouse) [20-44] (Table 1). As the expression of RCAN1 is extremely low in astrocytes and microglial cells, few study has been performed in glial cells [47-48]. However, it has to be noted that RCAN1 has dual role in regulating calcinurin activity depending on its level and phosphorylation status [33-34, 49]. For example, increased RCAN1 expression inhibits calcineurin activity, while low level of RCAN1 stimulates calcineurin activity in vitro $[21,49]$. Calcineurin is a calcium/calmodulin dependent serine/threonine phosphatase, consisting of a catalytic subunit, calcineurin A, and a regulatory subunit, calcineurin B. By dephosphorylating NFAT, calcineurin promotes NFAT translocation into the nucleus contributing to a number of genes' transcription and subsequent events, e.g., cell proliferation, apoptosis, angiogenesis, synaptic plasticity, immune response and skeletal/cardiac muscle development. Dysregulation or dysfunction of calcineurin has been linked to both $\mathrm{AD}$ and cancer, suggesting that RCAN1 may be involved in the pathogenesis of both $\mathrm{AD}$ and cancer via calcineurin-dependent pathways. On the other hand, RCAN1 interacts with multiple protein partners, such as integrin $\alpha_{\mathrm{v}} \beta_{3}$, NF- $\kappa \mathrm{B}$, ubiquitouslyexpressed prefoldin-like chaperone (UXT) and signal transducer and activator of transcription 2 (STAT2), which may contribute to the calcineurin-independent functions, including cell proliferation, apoptosis and angiogenesis [50-53]. Accumulated evidence indicates that RCAN1 may play an important role in the inverse association between $\mathrm{AD}$ and some types of cancer via both common and differential processes.

\section{ALZHEIMER'S DISEASE AND CANCER}

\section{Alzheimer's disease}

$\mathrm{AD}$ is the most common cause of dementia, accounting for $50-75 \%$ of dementia [54]. Less than 5\% cases are early-onset $\mathrm{AD}(\mathrm{EOAD})$, who develop $\mathrm{AD}$ before age 65. For example, patients with Down syndrome (DS), caused by trisomy of chromosome 21, inevitably develop of $\mathrm{AD}$ pathology after middle age. The majority $\mathrm{AD}$ cases are late-onset $\mathrm{AD}$ (LOAD), who develop $\mathrm{AD}$ after age 65 [2]. In 2010, World Alzheimer International estimated approximately 36 million people suffering from dementia worldwide and it costs US $\$ 604$ billion. Due to the rapid increase in aging population, the $\mathrm{AD}$ prevalence is continuously increased worldwide and the costs will reach to US $\$ 1$ trillion by 2030 [54]. Progressive memory loss 
is the characteristic of $\mathrm{AD}$, while cognitive deficits and psychosis may also be presented [55-57]. Extraneuronal neuritic plaques, intraneuronal neurofibrillary tangles, and synaptic/neuronal loss leading to brain atrophy are the pathological characteristics of $\mathrm{AD}$, while neuritic plaque is the unique feature of $\mathrm{AD}$ neuropathology [5867]. Amyloid $\beta(\mathrm{A} \beta)$ and phosphorylated Tau are the major components of neuritic plaques and neurofibrillary tangles, respectively [66, 68-72].

\section{Cancer}

Cancer is a group of diseases characterized with impaired cell growth control, poor differentiation and the potential to invade or spread to the other parts of the body although different types of cancer may be mediated by differential signaling pathways. It is one of the leading causes of death globally. Approximately 14 million

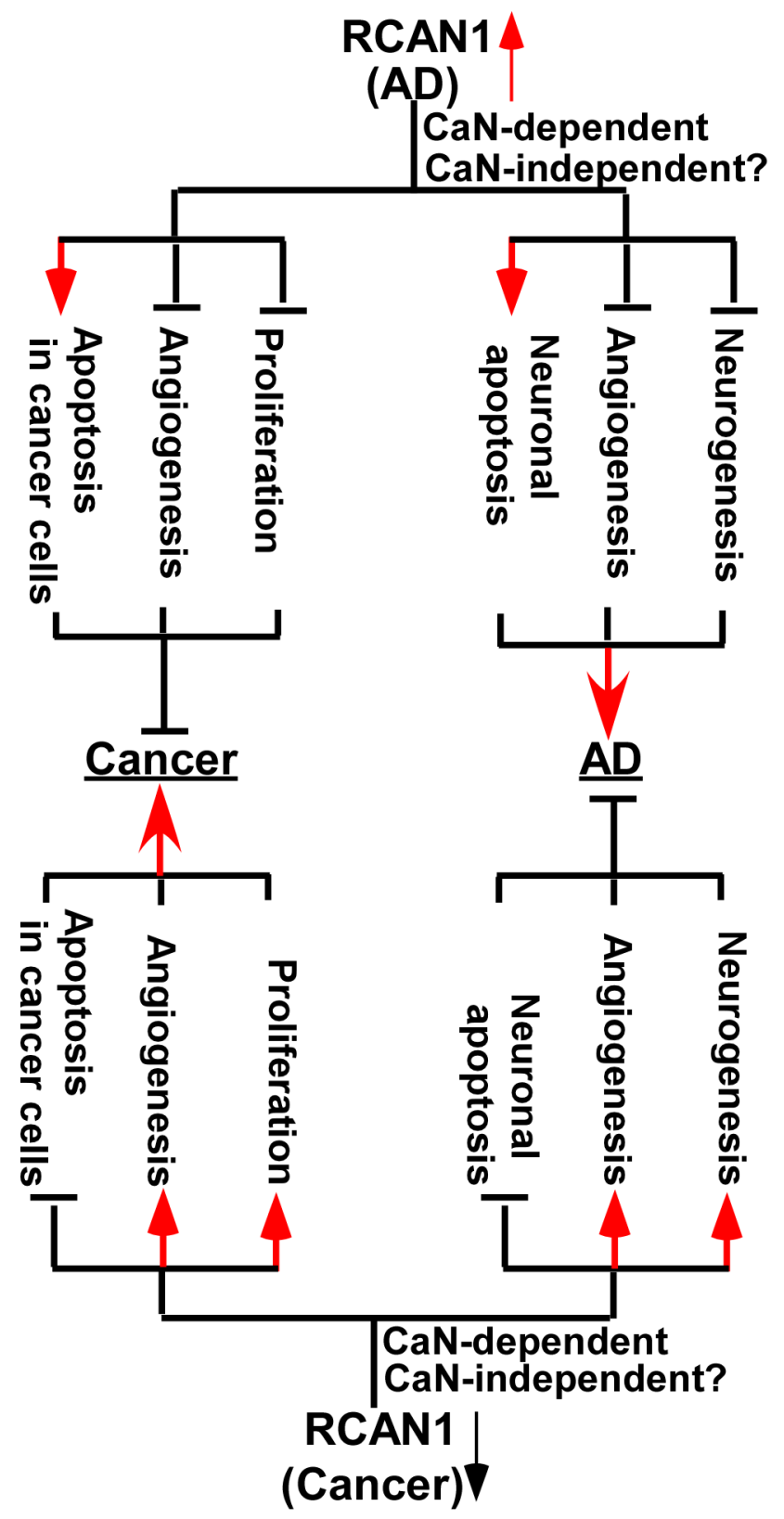

Figure 1: Mechanisms of RCAN1 in the inverse association between of Alzheimer's disease and cancer. Increased and decreased RCAN1 expression is detected in AD (top panel) and various types of cancer (bottom panel), respectively. Increased RCAN1 promotes $\mathrm{AD}$ pathogenesis by facilitating neuronal apoptosis, attenuating angiogenesis and inhibiting neurogenesis via calcineurin (CaN)dependent or -independent pathways (top panel). However, increased RCAN1 inhibits cancer development by promoting cancer cell apoptosis, attenuating angiogenesis and inhibiting cancer cell proliferation via calcineurin-dependent or -independent pathways (top panel). On the other hand, reduced RCAN1 promotes cancer development by attenuating cancer cell apoptosis, facilitating angiogenesis and promoting cancer cell proliferation, while it inhibits AD pathogenesis by attenuating neuronal apoptosis, facilitating angiogenesis and promoting neurogenesis via calcineurin-dependent or -independent pathways (bottom panel). 
new cases were diagnosed in 2012 and the number is expected to rise $70 \%$ over the next 2 decades [73]. 8.8 million people died from cancer in 2015 and the costs are US \$ 1.16 trillion in 2010 [73]. Although aging is also a fundamental factor for cancer development, the inverse association between $\mathrm{AD}$ and cancer has been reported in a number of studies [4-7]. A significant improvement has been made in cancer prevention and treatment in the past decades. However, there is no effective treatment for AD. Thus, elucidating mechanisms of the inverse association between $\mathrm{AD}$ and cancer will be beneficial to developing effective therapy for $\mathrm{AD}$ and cancer, particularly for $\mathrm{AD}$, as there is no effective treatment for AD.

\section{The inverse association between $\mathrm{AD}$ and cancer}

The inverse association between $\mathrm{AD}$ and cancer has been reported in several population-based studies and meta-analysis [4-15]. For example, cancer history is associated with the delay and reduced risk of AD onset [14-15]. Musicco et al. reported that the risk of AD among patients with cancer was $35 \%$ reduced and the risk of cancer in patients with AD nearly halved [6]. In addition, the risk of occurrence was significantly reduced for lung and colorectal cancer although the five most frequent sites of cancer in patients with AD dementia was lower [6]. Realmuto et al. showed that frequency of cancers at sites of breast, uterus, ovary and skin was reduced in AD cases compared with that in the controls [9]. Freedman et al. reported that six cancer sites (e.g., rectum, breast, uterus, ovary, prostate, leukemia) were significantly and inversely related to $\mathrm{AD}$ [12]. However, the association between AD and site-specific cancers remains inconclusive according to the most recent meta-analysis and systematic review $[7,10,74]$.

\section{DYSREGULATION OF RCAN1 IN ALZHEIMER'S DISEASE AND VARIOUS TYPES OF CANCER}

Increased RCAN1 expression is detected in AD brains [17-18, 48]. Moreover, multiple risk factors may be involved in its upregulation. For example, glucocorticoid, increased in $\mathrm{AD}$ patients, upregulates RCAN1.1 transcription in addition to promoting $A \beta$ generation and tau hyperphosphorylation [17, 75-82]. Apolipoprotine E (ApoE4) allele, a well-known risk factor of AD, significantly increases RCAN1 expression [83]. Ischemic stroke, a risk factor of $\mathrm{AD}$, markedly increases RCAN1.4 expression [84-85]. In addition, RCAN1 gene polymorphisms within the promoter region are associated with $\mathrm{AD}$ [86]. Moreover, NF- $\mathrm{BB}$, an inflammatory molecule, could activate RCAN1 transcription and block its degradation, leading to its upregulation [87-88].

RCAN1 dysregulation has also been detected in some types of cancer and cancer cells. For example, RCAN1.4 expression is reduced in some cancer cell lines at both transcriptional and post-translational levels, e.g., melanoma and thyroid cancer cells [89]. RCAN1 expression is significantly lower in lymph node metastasis compared with that in the primary tumor in papillary thyroid cancer [90]. Recently, Jin et al. reported that RCAN1.4 expression is significantly reduced in hepatocellular carcinoma compared with that in the adjacent non-cancer tissues [91]. Metastin, a tumor metastasis suppressor, increases RCAN1.4 expression in thyroid cancer cells [90]. In addition, NFAT family members, downstream targets of RCAN1, are constitutively activated in several types of cancer, including breast cancer, pancreatic cancer, aggressive $\mathrm{T}$ cell lymphoma, Burkitt's lymphoma, and diffuse large $B$ cell lymphoma, suggesting that the inhibitory effect of RCAN1 on calcineurin/NFAT may be reduced by its downregulation [92]. However, increased expression of RCAN1.4 has also been detected in other types of cancer, such as hypopharyngeal cancer and Kaposi's Sarcoma (KS) [93-94].

\section{MECHANISMS OF RCAN1 IN THE INVERSE ASSOCIATION BETWEEN ALZHEIMER'S DISEASE AND CANCER}

In addition to facilitating $A \beta$ generation and Tau phosphorylation in $\mathrm{AD}$, growing evidence suggests that RCAN1 is involved in several common processes in $\mathrm{AD}$ and cancer, such as apoptosis, cell proliferation and angiogenesis [95-97] (Table 2). DS patients inevitably develop AD pathology after middle age and the incidence of cancer is different from the controls, including lower incidence of some types of solid cancer and higher incidence of leukemia [98-102]. However, DS is not a proper model to represent the role of RCAN1 in the association between $\mathrm{AD}$ and cancer because of the following reasons. Although the expression of RCAN1 is increased in DS patients by an extra copy of the $R C A N 1$ gene, it has to be noted that DS is caused by an extra copy of chromosome 21 , which consists of more than 160 coding genes and a number of microRNAs in addition to the RCAN1 gene. Thus, DS could not fully reflect RCAN1's function. Moreover, many genes on chromosome 21 are implicated in cancer development, such as amyloid- $\beta$ precursor protein $(A P P)$, superoxide dismutase 1(SOD1), dual specificity tyrosine phosphorylation regulated kinase 1A (DYRK1A) etc., suggesting that the alteration of the incidence of cancer in DS is attributed to the combined effect of multiple genes [103-105]. Therefore, the altered incidence of cancer in DS is not discussed in the manuscript. 
Table 2: Mechanisms of RCAN1 in AD and cancer

\begin{tabular}{|c|c|c|c|c|}
\hline $\begin{array}{l}\text { Experimental } \\
\text { condition }\end{array}$ & $\begin{array}{l}\text { CaN interaction/ } \\
\text { activity }\end{array}$ & Cells/species & Affected phenotypes & References \\
\hline \multicolumn{5}{|l|}{ Apoptosis } \\
\hline In vitro & & Mouse primary neuron & Apoptosis & [139] \\
\hline In vitro & + & $\begin{array}{ll}\text { Mouse } & \text { primary } \\
\text { neuron, } & \\
\text { SH-SY5Y } & \\
\end{array}$ & Apoptosis & {$[17-18,107,109]$} \\
\hline In vivo & & ST14A(neuronal) & Apoptosis & {$[106]$} \\
\hline \multicolumn{5}{|l|}{ In vitro } \\
\hline \multirow[t]{2}{*}{ In vitro } & & Drosophila (neuron) & Apoptosis & [29] \\
\hline & & $\begin{array}{l}\text { U87MG cells (human } \\
\text { glioblastoma cells) }\end{array}$ & Apoptosis & {$[140]$} \\
\hline In vitro & & $\begin{array}{l}\text { U251, T98G (glioma } \\
\text { cells) }\end{array}$ & Apoptosis & [110] \\
\hline In vitro & & $\begin{array}{l}\text { CEM, } \\
\text { Nalm-6 } \\
\text { (leukemia cells) }\end{array}$ & Apoptosis & [111-113] \\
\hline $\begin{array}{l}\text { In vitro \& } \\
\text { in vivo }\end{array}$ & + & Burkitt's lymphoma & Apoptosis & {$[53]$} \\
\hline \multicolumn{5}{|l|}{ Angiogenesis } \\
\hline $\begin{array}{l}\text { In vitro \& } \\
\text { in vivo }\end{array}$ & + & \begin{tabular}{|l|} 
HUVEC \\
Primary endothelial \\
cell \\
mouse \\
\end{tabular} & $\begin{array}{l}\text { Angiogenesis: } \\
\text { proliferation and tube } \\
\text { formation }\end{array}$ & {$[16,117-118]$} \\
\hline $\begin{array}{l}\text { In vitro \& } \\
\text { in vivo }\end{array}$ & + & $\begin{array}{l}\text { HUVEC } \\
\mathrm{X} . \text { laevis } \\
\end{array}$ & $\begin{array}{l}\text { Angiogenesis: vascular } \\
\text { branching }\end{array}$ & $\begin{array}{l}\text { (Fujiwara et al., } \\
\text { 2011) }\end{array}$ \\
\hline \multicolumn{5}{|c|}{ Proliferation and migration } \\
\hline In vivo & & $\begin{array}{l}\text { RCAN1 transgenic } \\
\text { mice }\end{array}$ & $\begin{array}{l}\text { Neurogenesis: } \\
\text { Proliferation, } \\
\text { migration, } \\
\text { Maturation } \\
\end{array}$ & [126] \\
\hline In vitro & & $\begin{array}{l}\text { PC-12 cells } \\
\text { (pheochromocytoma } \\
\text { cells) }\end{array}$ & Proliferation & {$[130]$} \\
\hline In vitro & + & $\begin{array}{l}\text { MHCC97H, HCCLM3 } \\
\text { (hepatocellular } \\
\text { carcinoma cells) }\end{array}$ & $\begin{array}{l}\text { Proliferation, } \\
\text { Migration }\end{array}$ & {$[91]$} \\
\hline In vitro & + & $\begin{array}{l}\text { ARO, NPA } \\
\text { (human thyroid } \\
\text { carcinoma cells) }\end{array}$ & Proliferation & {$[90]$} \\
\hline In vitro & & $\begin{array}{l}\text { ARO, WRO, NPA, } \\
\text { FTC133 }\end{array}$ & Migration & [89]. \\
\hline In vitro & & $\begin{array}{l}\text { U87MG } \\
\text { (glioblastoma) }\end{array}$ & Proliferation & [129] \\
\hline In vitro \&in vivo & & $\begin{array}{l}\text { 8505c, BCPAP, C643, } \\
\text { FTC236 and SW1736 } \\
\text { (Human thyroid } \\
\begin{array}{l}\text { cancer cell lines), } \\
\text { mouse }\end{array}\end{array}$ & Proliferation & {$[127]$} \\
\hline In vitro & & $\begin{array}{l}\text { Ishikawa cells } \\
\text { (endometrial } \\
\text { adenocarcinoma) }\end{array}$ & proliferation & [128] \\
\hline
\end{tabular}




\section{RCAN1 PROMOTES APOPTOSIS}

\section{RCAN1 promotes neuronal apoptosis in AD}

Increased RCAN1-induced apoptosis promotes $\mathrm{AD}$ pathogenesis but suppresses the development and progression of cancer. Many studies indicate that increased RCAN1 expression plays a pivotal role in the pathogenesis of AD by promoting neuronal apoptosis. First, RCAN1.1S overexpression and chronic RCAN1.1L overexpression inhibit calcineurin activity and promote caspase-3mediated neuronal apoptosis, while acute RCAN1.1L overexpression protects neurons from stress-induced apoptosis by inhibiting caspase-3 activity [17-18]. Chronic overexpression of RCAN1.1L and RCAN1.1S impairs the function of mitochondria by promoting its degradation and accelerating ATP-ADP exchange rate, respectively, contributing to neuronal apoptosis [106]. Increased RCAN1.1 promotes $A \beta$-induced neuronal apoptosis in Drosophila, while RCAN1.4 expression promotes calcium overloading-induced neuronal apoptosis in vitro [29, 107]. In addition, RCAN1 overexpression dramatically increases Tau phosphorylation and $\mathrm{A} \beta$ generation, which also contributes to neuronal apoptosis in $\mathrm{AD}[97,108]$. Moreover, increased RCAN1.1L is a key mediator in amyloid precursor protein (APP) overexpression-induced neuronal apoptosis, while APP elevation is involved in the pathogenesis of both familial AD and sporadic AD [109].

\section{RCAN1 promotes cell apoptosis in various types of cancer}

Increased RCAN1 facilitates cancer cell apoptosis, which is a possible mechanism of inhibiting cancer development and progression. For example, increased RCAN1.1 or RCAN1.4 promotes lymphoma glioma cell apoptosis in vitro and in vivo by inhibiting the nuclear translocation of NF- $\mathrm{\kappa B}[53,110]$. Moreover, RCAN1.1 is an important mediator in glucocorticoid-induced apoptosis in leukemia cells by downregulating and upregulating anti-apoptotic and pro-apoptotic proteins, respectively [111-113].

\section{RCAN1 suppresses angiogenesis}

Alteration of angiogenesis is implicated in the pathogenesis of $\mathrm{AD}$ and cancer. Angiogenesis deficits involved in $\mathrm{AD}$ pathogenesis[114]. For example, vascular endothelial growth factor (VEGF), a factor facilitating angiogenesis, associates with optimal brain aging and might be a potential therapy against AD [115-116]. However, angiogenesis is a major mechanism of cancer development and progression. Accumulated evidence indicates that RCAN1 participates in endothelial cell migration and angiogenesis mediated by both calcineurin/ NFAT dependent and independent signaling. Most studies indicated that RCAN1.4 inhibits angiogenesis in vitro or in vivo. For example, Minami et al. reported that constitutive expression of RCAN1.4 impairs endothelia cell proliferation and tube formation, leading to the inhibition of angiogenesis and tumor growth in mice [117]. Consistently, Yao et al. reported that RCAN1.4 could act as an inhibitor of angiogenesis by regulating calcineurin/NFAT signaling [118]. More importantly, Baek et al. found that mild increase of RCAN1 expression by an extra copy of $R C A N 1$ gene suppresses tumor growth by inhibiting tumor angiogenesis in mice [16]. In addition, RCAN1 inhibits vascular branching during angiogenesis in vivo [119]. The aforementioned evidence indicates that mild increase of RCAN1 expression may contribute to the inverse association between $\mathrm{AD}$ and some type of cancer by suppressing angiogenesis.

Several reports showed that increased expression of RCAN1.4 is associated with angiogenesis in hypopharyngeal cancer and Kaposi's Sarcoma (KS) caused by Kaposi's Sarcoma Herpesvirus (KSHV) [9394], suggesting that increased RCAN1 expression may only be responsible for the inverse association of $\mathrm{AD}$ and some types but not all types of cancer. In addition, Ryeom et al. reported that RCAN1 knock-out inhibits angiogenesis and tumor growth in mice [120]. However, it has to be noted that low level of RCAN1 is necessary for calcineurin/NFAT activity [21, 49, 121].

\section{RCAN1 inhibits cell proliferation and migration}

RCAN1 plays a pivotal role in cell proliferation and migration, which are implicated in both neurogenesis in $\mathrm{AD}$, and tumor growth and metastasis in cancer [122-125].

\section{RCAN1 inhibits neurogenesis in AD}

Casas et al. first reported that RCAN1 is involved in neurogenesis, including neural progenitor cell proliferation, migration and maturation [123]. Moreover, the number of neurons within hippocampus is reduced in RCAN1 transgenic mice, which is associated with the defect in neural progenitor cell proliferation [126]. In addition, RCAN1 significantly inhibits neuronal maturation, which is characterized with reduced dendritic spines [126]. Thus, increased RCAN1 contribute to neurogenesis defect in AD by impairing neural progenitor cell proliferation, migration and maturation.

\section{RCAN1 inhibits cell proliferation and migration in various types of cancer}

Increased RCAN1.4 expression leads to growth arrest of fibroblast cells [42]. RCAN1.4 knockdown promotes tumor growths, which is mediated by nuclear factor erythroid 2-like 3 (NFE2L3) [127]. In addition, 
RCAN1-4 inhibits epithelial cell proliferation in endometrial adenocarcinoma via a negative regulation of C-X-C motif chemokine ligand 8 (CXCL8) [128]. Moreover, RCAN1.4, downregulated in hepatocellular carcinoma, prevents cancer cell proliferation and migration [91]. However, reduced RCAN1.4 expression attenuates proliferation of glioblastoma cells mediated by inhibiting Ras signaling, which is independent of calcineurin [129]. RCAN1.1S stimulates the proliferation of pheochromocytoma PC-12 cells [130]. The aforementioned evidence indicates that RCAN1 differentially regulates cell proliferation in various types of cancer. Moreover, RCAN1.4 could block cell migration to inhibit metastasis in papillary thyroid cancer [90]. Consistently, increased RCAN1 expression inhibits cancer cell migration, while loss of endogenous RCAN1 leads to an increase in migration in a couple of cancer cell lines, such as ARO, WRO, NPA and FTC133 [89]. Reduced RCAN1.4 expression are associated with advanced tumor stages and poor differentiation of hepatocellular carcinoma, while increased RCAN1.4 markedly reduces cancer cell proliferation and migration in hepatocellular carcinoma cells [91]. It suggests that RCAN1 could inhibit cancer development and progression by inhibiting both cancer cell proliferation and migration.

\section{THERAPEUTIC POTENTIAL OF REGULATING RCAN1 FOR THE TREATMENT OF AD AND CANCER}

Although accumulated evidence indicates that RCAN1 might be a potential target for the treatment of $\mathrm{AD}$ and certain types of cancer, currently, no drug is developed based on the regulation of RCAN1. To develop drugs based on RCAN1 regulation, the following issues should be considered. First, calcineurin inhibitors have been widely used as the immunosuppressive drug in the organ transplantation and certain types of autoimmune disorders. Thus, the role of RCAN1 in immune function should be considered, which is implicated in both $\mathrm{AD}$ and cancer. However, studies of RCAN1 in immunity are limited [131-132]. Second, it has to be noted that RCAN1 has a bidirectional role in regulating calcineurin activity depending on its expression level and phosphorylation status, which is not just a calcineurin inhibitor or stimulator [45]. Thus, precisely regulating RCAN1 activity needs to be carefully investigated. In addition, the isoform specific effect remains unclear. Moreover, the calcineurin-independent function is less studied. However, it is critical for developing RCAN1-based drugs.

\section{CONCLUSIONS}

The inverse association between Alzheimer's disease (AD) and cancer has been reported in several population-based studies. Although the underlying mechanisms remain elusive, growing evidence indicates that RCAN1 is a key molecule of the inverse association. Increased and decreased RCAN1 expression are detected in $\mathrm{AD}$ and various types of cancer, respectively. Moreover, increased RCAN1 promotes AD pathogenesis by facilitating neuronal apoptosis, attenuating angiogenesis and inhibiting neurogenesis via calcineurin-dependent or -independent pathways. However, increased RCAN1 inhibits cancer development by promoting cancer cell apoptosis, attenuating angiogenesis and inhibiting cancer cell proliferation via calcineurin-dependent or -independent pathways (Fig. 1). On the other hand, reduced RCAN1 promotes cancer development by attenuating cancer cell apoptosis, facilitating angiogenesis and promoting cancer cell proliferation, while it inhibits $\mathrm{AD}$ pathogenesis by attenuating neuronal apoptosis, facilitating angiogenesis and promoting neurogenesis via calcineurin-dependent or -independent pathways (Fig. 1). Therefore, increased RCAN1 expression may contribute to the reduced incidence of some types of cancer in $\mathrm{AD}$ patients, while reduced RCAN1 expression may reduce the risk of $\mathrm{AD}$ in patients with various types of cancer. It suggested that dysregulation of RCAN1 plays a key role in the pathogenesis of both $\mathrm{AD}$ and cancer. Although precisely modulating the expression of RCAN1 may be a potential therapeutic target to treat $\mathrm{AD}$ and cancer, several key issues need to be resolved for drug development.

\section{CONFLICTS OF INTEREST}

The authors declare no conflict of interest.

\section{FUNDING}

This work was supported by Natural Science Foundation of Shandong Province (ZR2016HM30) and National Natural Science Fund of China (81771147).

\section{REFERENCES}

1. World Alzheimer Report AD. 2010. https://www.alz.co.uk/ research/files/WorldAlzheimerReport2010.pdf.

2. Alzheimer's Association. 2012 Alzheimer's disease facts and figures. Alzheimers Dement. 2012; 8: 131-68.

3. McGuire S. World Cancer Report 2014. Geneva, Switzerland: World Health Organization, International Agency for Research on Cancer, WHO Press, 2015. Adv Nutr. 2016; 7: 418-9.

4. Roe CM, Behrens MI, Xiong C, Miller JP, Morris JC. Alzheimer disease and cancer. Neurology. 2005; 64: 895-8.

5. Driver JA, Beiser A, Au R, Kreger BE, Splansky GL, Kurth T, Kiel DP, Lu KP, Seshadri S, Wolf PA. Inverse association between cancer and Alzheimer's disease: results from the Framingham Heart Study. BMJ. 2012; 344: e1442. 
6. Musicco M, Adorni F, Di Santo S, Prinelli F, Pettenati C, Caltagirone C, Palmer K, Russo A. Inverse occurrence of cancer and Alzheimer disease: a population-based incidence study. Neurology. 2013; 81: 322-8.

7. Catala-Lopez F, Crespo-Facorro B, Vieta E, Valderas JM, Valencia A, Tabares-Seisdedos R. Alzheimer's disease and cancer: current epidemiological evidence for a mutual protection. Neuroepidemiology. 2014; 42: 121-2.

8. Roe CM, Fitzpatrick AL, Xiong C, Sieh W, Kuller L, Miller JP, Williams MM, Kopan R, Behrens MI, Morris JC. Cancer linked to Alzheimer disease but not vascular dementia. Neurology. 2010; 74: 106-12.

9. Realmuto S, Cinturino A, Arnao V, Mazzola MA, Cupidi C, Aridon P, Ragonese P, Savettieri G, D’Amelio M. Tumor diagnosis preceding Alzheimer's disease onset: is there a link between cancer and Alzheimer's disease? J Alzheimers Dis. 2012; 31: 177-82.

10. Catala-Lopez F, Suarez-Pinilla M, Suarez-Pinilla P, Valderas JM, Gomez-Beneyto M, Martinez S, BalanzaMartinez V, Climent J, Valencia A, McGrath J, CrespoFacorro B, Sanchez-Moreno J, Vieta E, et al. Inverse and direct cancer comorbidity in people with central nervous system disorders: a meta-analysis of cancer incidence in 577,013 participants of 50 observational studies. Psychother Psychosom. 2014; 83: 89-105.

11. Catala-Lopez F, Tabares-Seisdedos R. Alzheimer's disease and cancer: the need of putting research into context with previous published systematic reviews. J Cancer Res Clin Oncol. 2015; 141: 569-70.

12. Freedman DM, Wu J, Chen H, Kuncl RW, Enewold LR, Engels EA, Freedman ND, Pfeiffer RM. Associations between cancer and Alzheimer's disease in a U.S. Medicare population. Cancer Med. 2016; 5: 2965-76.

13. Tabares-Seisdedos R, Rubenstein JL. Inverse cancer comorbidity: a serendipitous opportunity to gain insight into CNS disorders. Nat Rev Neurosci. 2013; 14: 293-304.

14. Nudelman KN, Risacher SL, West JD, McDonald BC, Gao S, Saykin AJ, and Alzheimer's Disease Neuroimaging Initiative. Association of cancer history with Alzheimer's disease onset and structural brain changes. Front Physiol. 2014; 5: 423.

15. Schmidt SA, Ording AG, Horvath-Puho E, Sorensen HT, Henderson VW. Non-melanoma skin cancer and risk of Alzheimer's disease and all-cause dementia. PLoS One. 2017; 12: e0171527.

16. Baek KH, Zaslavsky A, Lynch RC, Britt C, Okada Y, Siarey RJ, Lensch MW, Park IH, Yoon SS, Minami T, Korenberg JR, Folkman J, Daley GQ, et al. Down's syndrome suppression of tumour growth and the role of the calcineurin inhibitor DSCR1. Nature. 2009; 459: 1126-30.

17. Sun X, Wu Y, Chen B, Zhang Z, Zhou W, Tong Y, Yuan J, Xia K, Gronemeyer H, Flavell RA, Song W. Regulator of calcineurin 1 (RCAN1) facilitates neuronal apoptosis through caspase-3 activation. J Biol Chem. 2011; 286:
9049-62.

18. Wu Y, Song W. Regulation of RCAN1 translation and its role in oxidative stress-induced apoptosis. FASEB J. 2013; 27: 208-21.

19. Davies KJ, Ermak G, Rothermel BA, Pritchard M, Heitman J, Ahnn J, Henrique-Silva F, Crawford D, Canaider S, Strippoli P, Carinci P, Min KT, Fox DS, et al. Renaming the DSCR1/Adapt78 gene family as RCAN: regulators of calcineurin. FASEB J. 2007; 21: 3023-8.

20. Mehta S, Li H, Hogan PG, Cunningham KW. Domain architecture of the regulators of calcineurin (RCANs) and identification of a divergent RCAN in yeast. Mol Cell Biol. 2009; 29: 2777-93.

21. Hilioti Z, Gallagher DA, Low-Nam ST, Ramaswamy P, Gajer P, Kingsbury TJ, Birchwood CJ, Levchenko A, Cunningham KW. GSK-3 kinases enhance calcineurin signaling by phosphorylation of RCNs. Genes Dev. 2004; 18: 35-47.

22. Gorlach J, Fox DS, Cutler NS, Cox GM, Perfect JR, Heitman J. Identification and characterization of a highly conserved calcineurin binding protein, CBP1/calcipressin, in Cryptococcus neoformans. EMBO J. 2000; 19: 3618-29.

23. Strippoli P, Lenzi L, Petrini M, Carinci P, Zannotti M. A new gene family including DSCR1 (Down Syndrome Candidate Region 1) and ZAKI-4: characterization from yeast to human and identification of DSCR1-like 2, a novel human member (DSCR1L2). Genomics. 2000; 64: 252-63.

24. Lee JI, Dhakal BK, Lee J, Bandyopadhyay J, Jeong SY, Eom SH, Kim DH, Ahnn J. The Caenorhabditis elegans homologue of Down syndrome critical region 1, RCN-1, inhibits multiple functions of the phosphatase calcineurin. J Mol Biol. 2003; 328: 147-56.

25. Li W, Choi TW, Ahnn J, Lee SK. Allele-Specific Phenotype Suggests a Possible Stimulatory Activity of RCAN-1 on Calcineurin in Caenorhabditis elegans. Mol Cells. 2016; 39: 827-33.

26. Chang KT, Shi YJ, Min KT. The Drosophila homolog of Down's syndrome critical region 1 gene regulates learning: implications for mental retardation. Proc Natl Acad Sci U S A. 2003 ; 100: 15794-9.

27. Chang KT, Min KT. Upregulation of three Drosophila homologs of human chromosome 21 genes alters synaptic function: implications for Down syndrome. Proc Natl Acad Sci U S A. 2009; 106: 17117-22.

28. Shaw JL, Chang KT. Nebula/DSCR1 upregulation delays neurodegeneration and protects against APP-induced axonal transport defects by restoring calcineurin and GSK-3beta signaling. PLoS Genet. 2013; 9: e1003792.

29. Lee S, Bang SM, Hong YK, Lee JH, Jeong H, Park SH, Liu QF, Lee IS, Cho KS. The calcineurin inhibitor Sarah (Nebula) exacerbates Abeta42 phenotypes in a Drosophila model of Alzheimer's disease. Dis Model Mech. 2016; 9: 295-306.

30. Rothermel BA, Vega RB, Williams RS. The role of 
modulatory calcineurin-interacting proteins in calcineurin signaling. Trends Cardiovasc Med. 2003; 13: 15-21.

31. Oh M, Rybkin II, Copeland V, Czubryt MP, Shelton JM, van Rooij E, Richardson JA, Hill JA, De Windt LJ, BasselDuby R, Olson EN, Rothermel BA. Calcineurin is necessary for the maintenance but not embryonic development of slow muscle fibers. Mol Cell Biol. 2005; 25: 6629-38.

32. Arron JR, Winslow MM, Polleri A, Chang CP, Wu H, Gao X, Neilson JR, Chen L, Heit JJ, Kim SK, Yamasaki $\mathrm{N}$, Miyakawa T, Francke U, et al. NFAT dysregulation by increased dosage of DSCR1 and DYRK1A on chromosome 21. Nature. 2006; 441: 595-600.

33. Sanna B, Brandt EB, Kaiser RA, Pfluger P, Witt SA, Kimball TR, van Rooij E, De Windt LJ, Rothenberg ME, Tschop MH, Benoit SC, Molkentin JD. Modulatory calcineurin-interacting proteins 1 and 2 function as calcineurin facilitators in vivo. Proc Natl Acad Sci U S A. 2006; 103: 7327-32.

34. Shin SY, Choo SM, Kim D, Baek SJ, Wolkenhauer O, Cho $\mathrm{KH}$. Switching feedback mechanisms realize the dual role of MCIP in the regulation of calcineurin activity. FEBS Lett. 2006; 580: 5965-73.

35. Hoeffer CA, Dey A, Sachan N, Wong H, Patterson RJ, Shelton JM, Richardson JA, Klann E, Rothermel BA. The Down syndrome critical region protein RCAN1 regulates long-term potentiation and memory via inhibition of phosphatase signaling. J Neurosci. 2007; 27: 13161-72.

36. van Rooij E, Doevendans PA, Crijns HJ, Heeneman S, Lips DJ, van Bilsen M, Williams RS, Olson EN, Bassel-Duby R, Rothermel BA, De Windt LJ. MCIP1 overexpression suppresses left ventricular remodeling and sustains cardiac function after myocardial infarction. Circ Res. 2004; 94: e18-26.

37. Fuentes JJ, Genesca L, Kingsbury TJ, Cunningham KW, Perez-Riba M, Estivill X, de la Luna S. DSCR1, overexpressed in Down syndrome, is an inhibitor of calcineurin-mediated signaling pathways. Hum Mol Genet. 2000; 9: 1681-90.

38. Abbasi S, Lee JD, Su B, Chen X, Alcon JL, Yang J, Kellems RE, Xia Y. Protein kinase-mediated regulation of calcineurin through the phosphorylation of modulatory calcineurin-interacting protein 1. J Biol Chem. 2006; 281: 7717-26.

39. Liu Q, Busby JC, Molkentin JD. Interaction between TAK1-TAB1-TAB2 and RCAN1-calcineurin defines a signalling nodal control point. Nat Cell Biol. 2009; 11: 15461.

40. Kim SS, Seo SR. The regulator of calcineurin 1 (RCAN1/ DSCR1) activates the cAMP response element-binding protein (CREB) pathway. J Biol Chem. 2011; 286: 37841-8.

41. Noh EH, Hwang HS, Min B, Im E, Chung KC. Covalent NEDD8 conjugation increases RCAN1 protein stability and potentiates its inhibitory action on calcineurin. PLoS One. 2012; 7: e48315.
42. Leahy KP, Crawford DR. adapt78 protects cells against stress damage and suppresses cell growth. Arch Biochem Biophys. 2000; 379: 221-8.

43. Rothermel BA, McKinsey TA, Vega RB, Nicol RL, Mammen P, Yang J, Antos CL, Shelton JM, Bassel-Duby R, Olson EN, Williams RS. Myocyte-enriched calcineurininteracting protein, MCIP1, inhibits cardiac hypertrophy in vivo. Proc Natl Acad Sci USA. 2001; 98:3328-33.

44. Pedram A, Razandi M, Aitkenhead M, Levin ER. Estrogen inhibits cardiomyocyte hypertrophy in vitro. Antagonism of calcineurin-related hypertrophy through induction of MCIP1. J Biol Chem. 2005; 280: 26339-48.

45. Wu Y, Ly PT, Song W. Aberrant expression of RCAN1 in Alzheimer's pathogenesis: a new molecular mechanism and a novel drug target. Mol Neurobiol. 2014; 50: 1085-97.

46. Harris CD, Ermak G, Davies KJ. Multiple roles of the DSCR1 (Adapt78 or RCAN1) gene and its protein product calcipressin 1 (or RCAN1) in disease. Cell Mol Life Sci. 2005; 62: 2477-86.

47. Ermak G, Morgan TE, Davies KJ. Chronic overexpression of the calcineurin inhibitory gene DSCR1 (Adapt78) is associated with Alzheimer's disease. J Biol Chem. 2001; 276: 38787-94.

48. Harris CD, Ermak G, Davies KJ. RCAN1-1L is overexpressed in neurons of Alzheimer's disease patients. FEBS J. 2007; 274: 1715-24.

49. Shin SY, Yang HW, Kim JR, Heo WD, Cho KH. A hidden incoherent switch regulates RCAN1 in the calcineurinNFAT signaling network. J Cell Sci. 2011; 124: 82-90.

50. Iizuka M, Abe M, Shiiba K, Sasaki I, Sato Y. Down syndrome candidate region 1,a downstream target of VEGF, participates in endothelial cell migration and angiogenesis. J Vasc Res. 2004; 41: 334-44.

51. Silveira HC, Sommer CA, Soares-Costa A, Henrique-Silva F. A calcineurin inhibitory protein overexpressed in Down's syndrome interacts with the product of a ubiquitously expressed transcript. Braz J Med Biol Res. 2004; 37: 785-9.

52. Lee JW, Kang HS, Lee JY, Lee EJ, Rhim H, Yoon JH, Seo $\mathrm{SR}$, Chung KC. The transcription factor STAT2 enhances proteasomal degradation of RCAN1 through the ubiquitin E3 ligase FBW7. Biochem Biophys Res Commun. 2012; 420: 404-10.

53. Liu C, Zheng L, Wang H, Ran X, Liu H, Sun X. The RCAN1 inhibits NF-kappaB and suppresses lymphoma growth in mice. Cell Death Dis. 2015; 6: e1929.

54. Alzheimer's Disease International. World Alzheimer Report 2014. 2014.

55. Hort J, O'Brien JT, Gainotti G, Pirttila T, Popescu BO, Rektorova I, Sorbi S, Scheltens P, and EFNS Scientist Panel on Dementia. EFNS guidelines for the diagnosis and management of Alzheimer's disease. Eur J Neurol. 2010; 17: 1236-48.

56. Segal-Gidan F, Cherry D, Jones R, Williams B, Hewett L, Chodosh J, and California Workgroup on Guidelines for 
Alzheimer's Disease Management. Alzheimer's disease management guideline: update 2008. Alzheimers Dement. 2011; 7: e51-9.

57. McKhann GM, Knopman DS, Chertkow H, Hyman BT, Jack CR Jr, Kawas CH, Klunk WE, Koroshetz WJ, Manly JJ, Mayeux R, Mohs RC, Morris JC, Rossor MN, et al. The diagnosis of dementia due to Alzheimer's disease: recommendations from the National Institute on AgingAlzheimer's Association workgroups on diagnostic guidelines for Alzheimer's disease. Alzheimers Dement. 2011; 7: 263-9.

58. Delacourte A, Defossez A. Alzheimer's disease: Tau proteins, the promoting factors of microtubule assembly, are major components of paired helical filaments. J Neurol Sci. 1986; 76: 173-86.

59. Grundke-Iqbal I, Iqbal K, Quinlan M, Tung YC, Zaidi MS, Wisniewski HM. Microtubule-associated protein tau. A component of Alzheimer paired helical filaments. J Biol Chem. 1986; 261: 6084--9.

60. Grundke-Iqbal I, Iqbal K, Tung YC, Quinlan M, Wisniewski HM, Binder LI. Abnormal phosphorylation of the microtubule-associated protein tau (tau) in Alzheimer cytoskeletal pathology. Proc Natl Acad Sci U S A. 1986; 83: 4913--7.

61. Ihara Y, Nukina N, Miura R, Ogawara M. Phosphorylated tau protein is integrated into paired helical filaments in Alzheimer's disease. J Biochem. 1986; 99: 1807--10.

62. Kosik KS, Joachim CL, Selkoe DJ. Microtubule-associated protein tau (tau) is a major antigenic component of paired helical filaments in Alzheimer disease. Proc Natl Acad Sci U S A. 1986; 83: 4044--8.

63. Wood JG, Mirra SS, Pollock NJ, Binder LI. Neurofibrillary tangles of Alzheimer disease share antigenic determinants with the axonal microtubule-associated protein tau (tau). Proc Natl Acad Sci U S A. 1986; 83: 4040--3.

64. Glenner GG, Wong CW. Alzheimer's disease and Down's syndrome: sharing of a unique cerebrovascular amyloid fibril protein. Biochem Biophys Res Commun. 1984; 122: 1131-5.

65. Glenner GG, Wong CW, Quaranta V, Eanes ED. The amyloid deposits in Alzheimer's disease: their nature and pathogenesis. Appl Pathol. 1984b; 2: 357-69.

66. Glenner GG, Wong CW. Alzheimer's disease: initial report of the purification and characterization of a novel cerebrovascular amyloid protein. Biochem Biophys Res Commun. 1984; 120: 885-90.

67. Mattson MP. Pathways towards and away from Alzheimer's disease. Nature. 2004; 430: 631-9.

68. Sun X, Bromley-Brits K, Song W. Regulation of beta-site APP-cleaving enzyme 1 gene expression and its role in Alzheimer's disease. J Neurochem. 2012; 120:62-70.

69. Wischik CM, Novak M, Edwards PC, Klug A, Tichelaar W, Crowther RA. Structural characterization of the core of the paired helical filament of Alzheimer disease. Proc Natl
Acad Sci U S A. 1988; 85: 4884-8.

70. Wischik CM, Novak M, Thogersen HC, Edwards PC, Runswick MJ, Jakes R, Walker JE, Milstein C, Roth M, Klug A. Isolation of a fragment of tau derived from the core of the paired helical filament of Alzheimer disease. Proc Natl Acad Sci U S A. 1988; 85: 4506-10.

71. Goedert M, Wischik CM, Crowther RA, Walker JE, Klug A. Cloning and sequencing of the cDNA encoding a core protein of the paired helical filament of Alzheimer disease: identification as the microtubule-associated protein tau. Proc Natl Acad Sci U S A. 1988; 85: 4051-5.

72. Weingarten MD, Lockwood AH, Hwo SY, Kirschner MW. A protein factor essential for microtubule assembly. Proc Natl Acad Sci U S A. 1975; 72: 1858-62.

73. Ferlay J, Soerjomataram I, Dikshit R, Eser S, Mathers C, Rebelo M, Parkin DM, Forman D, Bray F. Cancer incidence and mortality worldwide: sources, methods and major patterns in GLOBOCAN 2012. Int J Cancer. 2015; 136: E359-86.

74. Shi HB, Tang B, Liu YW, Wang XF, Chen GJ. Alzheimer disease and cancer risk: a meta-analysis. J Cancer Res Clin Oncol. 2015; 141: 485-94.

75. Masugi F, Ogihara T, Sakaguchi K, Otsuka A, Tsuchiya Y, Morimoto S, Kumahara Y, Saeki S, Nishide M. High plasma levels of cortisol in patients with senile dementia of the Alzheimer's type. Methods Find Exp Clin Pharmacol. 1989; 11: 707-10.

76. Arsenault-Lapierre G, Chertkow H, Lupien S. Seasonal effects on cortisol secretion in normal aging, mild cognitive impairment and Alzheimer's disease. Neurobiol Aging. 2010; 31: 1051-4.

77. Catania C, Sotiropoulos I, Silva R, Onofri C, Breen KC, Sousa N, Almeida OF. The amyloidogenic potential and behavioral correlates of stress. Mol Psychiatry. 2009; 14: 95-105.

78. de Leon MJ, McRae T, Tsai JR, George AE, Marcus DL, Freedman M, Wolf AP, McEwen B. Abnormal cortisol response in Alzheimer's disease linked to hippocampal atrophy. Lancet. 1988; 2: 391-2.

79. Green KN, Billings LM, Roozendaal B, McGaugh JL, LaFerla FM. Glucocorticoids increase amyloid-beta and tau pathology in a mouse model of Alzheimer's disease. J Neurosci. 2006; 26: 9047-56.

80. Laske C, Stransky E, Fritsche A, Eschweiler GW, Leyhe $\mathrm{T}$. Inverse association of cortisol serum levels with T-tau, P-tau 181 and P-tau 231 peptide levels and T-tau/Abeta 1-42 ratios in CSF in patients with mild Alzheimer's disease dementia. Eur Arch Psychiatry Clin Neurosci. 2009; 259: 80-5.

81. Yoshida NL, Miyashita T, U M, Yamada M, Reed JC, Sugita Y, Oshida T. Analysis of gene expression patterns during glucocorticoid-induced apoptosis using oligonucleotide arrays. Biochem Biophys Res Commun. 2002; 293: 1254-61. 
82. U M, Shen L, Oshida T, Miyauchi J, Yamada M, Miyashita $\mathrm{T}$. Identification of novel direct transcriptional targets of glucocorticoid receptor. Leukemia. 2004; 18: 1850-6.

83. Badia MC, Lloret A, Giraldo E, Dasi F, Olaso G, Alonso MD, Vina J. Lymphocytes from Young Healthy Persons Carrying the ApoE4 Allele Overexpress Stress-Related Proteins Involved in the Pathophysiology of Alzheimer's Disease. J Alzheimers Dis. 2013; 33:77-83.

84. Cho KO, Kim YS, Cho YJ, Kim SY. Upregulation of DSCR1 (RCAN1 or Adapt78) in the peri-infarct cortex after experimental stroke. Exp Neurol. 2008; 212: 85-92.

85. Sobrado M, Ramirez BG, Neria F, Lizasoain I, Arbones ML, Minami T, Redondo JM, Moro MA, Cano E. Regulator of calcineurin 1 (Rcan1) has a protective role in brain ischemia/reperfusion injury. J Neuroinflammation. 2012; 9: 48.

86. Lin KG, Tang M, Guo YB, Han HY, Lin YH. Two polymorphisms of RCAN1 gene associated with Alzheimer's disease in the Chinese Han population. East Asian Arch Psychiatry. 2011; 21: 79-84.

87. Zheng L, Liu H, Wang P, Song W, Sun X. Regulator of calcineurin 1 gene transcription is regulated by nuclear factor-kappaB. Curr Alzheimer Res. 2014; 11: 156-64.

88. Lee EJ, Seo SR, Um JW, Park J, Oh Y, Chung KC. NFkappaB-inducing kinase phosphorylates and blocks the degradation of Down syndrome candidate region 1. J Biol Chem. 2008; 283: 3392-400.

89. Espinosa AV, Shinohara M, Porchia LM, Chung YJ, McCarty S, Saji M, Ringel MD. Regulator of calcineurin 1 modulates cancer cell migration in vitro. Clin Exp Metastasis. 2009; 26: 517-26.

90. Stathatos N, Bourdeau I, Espinosa AV, Saji M, Vasko VV, Burman KD, Stratakis CA, Ringel MD. KiSS-1/G protein-coupled receptor 54 metastasis suppressor pathway increases myocyte-enriched calcineurin interacting protein 1 expression and chronically inhibits calcineurin activity. J Clin Endocrinol Metab. 2005; 90: 5432-40.

91. Jin H, Wang C, Jin G, Ruan H, Gu D, Wei L, Wang H, Wang N, Arunachalam E, Zhang Y, Deng X, Yang C, Xiong Y, et al. Regulator of Calcineurin 1 Gene Isoform 4, Downregulated in Hepatocellular Carcinoma, Prevents Proliferation, Migration, and Invasive Activity of Cancer Cells and Growth of Orthotopic Tumors by Inhibiting Nuclear Translocation of NFAT1. Gastroenterology. 2017; 153:799-811.e33.

92. Qin JJ, Nag S, Wang W, Zhou J, Zhang WD, Wang $\mathrm{H}$, Zhang R. NFAT as cancer target: mission possible? Biochim Biophys Acta. 2014; 1846: 297-311.

93. Lv C, Liu D, Wei X. Down syndrome critical region 1 positively correlates with angiogenesis in hypopharyngeal cancer. Mol Med Rep. 2017; 15: 263-70.

94. Bala K, Bosco R, Gramolelli S, Haas DA, Kati S, Pietrek M, Havemeier A, Yakushko Y, Singh VV, Dittrich-Breiholz O, Kracht M, Schulz TF. Kaposi's sarcoma herpesvirus
K15 protein contributes to virus-induced angiogenesis by recruiting PLCgamma1 and activating NFAT1-dependent RCAN1 expression. PLoS Pathog. 2012; 8: e1002927.

95. Ermak G, Pritchard MA, Dronjak S, Niu B, Davies KJ. Do RCAN1 proteins link chronic stress with neurodegeneration? FASEB J. 2011; 25: 3306-11.

96. Poppek D, Keck S, Ermak G, Jung T, Stolzing A, Ullrich O, Davies KJ, Grune T. Phosphorylation inhibits turnover of the tau protein by the proteasome: influence of RCAN1 and oxidative stress. Biochem J. 2006; 400: 511-20.

97. Wang T, Liu H, Wang Y, Liu C, Sun X. RCAN1 Increases Abeta Generation by Promoting N-glycosylation via Oligosaccharyltransferase. Curr Alzheimer Res. 2014; 11: 332-9.

98. Satge D, Sasco AJ, Carlsen NL, Stiller CA, Rubie H, Hero B, de Bernardi B, de Kraker J, Coze C, Kogner P, Langmark F, Hakvoort-Cammel FG, Beck D, et al. A lack of neuroblastoma in Down syndrome: a study from 11 European countries. Cancer Res. 1998; 58: 448-52.

99. Hasle H, Clemmensen IH, Mikkelsen M. Risks of leukaemia and solid tumours in individuals with Down's syndrome. Lancet. 2000; 355: 165-9.

100. Yang Q, Rasmussen SA, Friedman JM. Mortality associated with Down's syndrome in the USA from 1983 to 1997: a population-based study. Lancet. 2002; 359: 1019-25.

101. Xavier AC, Ge Y, Taub JW. Down syndrome and malignancies: a unique clinical relationship: a paper from the 2008 william beaumont hospital symposium on molecular pathology. J Mol Diagn. 2009; 11: 371-80.

102. Fores-Martos J, Cervera-Vidal R, Chirivella E, RamosJarero A, Climent J. A genomic approach to study down syndrome and cancer inverse comorbidity: untangling the chromosome 21. Front Physiol. 2015; 6: 10.

103. Papa L, Manfredi G, Germain D. SOD1, an unexpected novel target for cancer therapy. Genes Cancer. 2014; 5:1521. https://doi.org/10.18632/genesandcancer.4.

104. Abbassi R, Johns TG, Kassiou M, Munoz L. DYRK1A in neurodegeneration and cancer: Molecular basis and clinical implications. Pharmacol Ther. 2015; 151: 87-98.

105. Pandey P, Sliker B, Peters HL, Tuli A, Herskovitz J, Smits K, Purohit A, Singh RK, Dong J, Batra SK, Coulter DW, Solheim JC. Amyloid precursor protein and amyloid precursor-like protein 2 in cancer. Oncotarget. 2016; 7:19430-44. https://doi.org/10.18632/oncotarget.7103.

106. Ermak G, Sojitra S, Yin F, Cadenas E, Cuervo AM, Davies KJ. Chronic Expression of RCAN1-1L Protein Induces Mitochondrial Autophagy and Metabolic Shift from Oxidative Phosphorylation to Glycolysis in Neuronal Cells. J Biol Chem. 2012; 287: 14088-98.

107. Sun X, Wu Y, Herculano B, Song W. RCAN1 overexpression exacerbates calcium overloading-induced neuronal apoptosis. PLoS One. 2014; 9: e95471.

108. Ermak G, Harris CD, Battocchio D, Davies KJ. RCAN1 (DSCR1 or Adapt78) stimulates expression of GSK-3beta. 
FEBS J. 2006; 273: 2100-9.

109. Wu Y, Deng Y, Zhang S, Luo Y, Cai F, Zhang Z, Zhou W, Li T, Song W. Amyloid-beta precursor protein facilitates the regulator of calcineurin 1-mediated apoptosis by downregulating proteasome subunit alpha type-5 and proteasome subunit beta type-7. Neurobiol Aging. 2015; 36: 169-77.

110. Chen X, Hu Y, Wang S, Sun X. The regulator of calcineurin 1 (RCAN1) inhibits nuclear factor kappaB signaling pathway and suppresses human malignant glioma cells growth. Oncotarget. 2017; 8:12003-12. https://doi. org/10.18632/oncotarget.14479.

111. Saenz GJ, Hovanessian R, Gisis AD, Medh RD. Glucocorticoid-mediated co-regulation of RCAN1-1, E4BP4 and BIM in human leukemia cells susceptible to apoptosis. Biochem Biophys Res Commun. 2015; 463: 1291-6.

112. Nagao K, Iwai Y, Miyashita T. RCAN1 is an important mediator of glucocorticoid-induced apoptosis in human leukemic cells. PLoS One. 2012; 7: e49926.

113. Hirakawa Y, Nary LJ, Medh RD. Glucocorticoid evoked upregulation of RCAN1-1 in human leukemic CEM cells susceptible to apoptosis. J Mol Signal. 2009; 4: 6.

114. Ambrose CT. The Role of Capillaries in the Lesser Ailments of Old Age and in Alzheimer's Disease and Vascular Dementia: The Potential of Pro-Therapeutic Angiogenesis. J Alzheimers Dis. 2016; 54: 31-43.

115. Hohman TJ, Bell SP, Jefferson AL, and Alzheimer's Disease Neuroimaging Initiative. The role of vascular endothelial growth factor in neurodegeneration and cognitive decline: exploring interactions with biomarkers of Alzheimer disease. JAMA Neurol. 2015; 72: 520-9.

116. Echeverria V, Barreto GE, Avila-Rodriguez M, Tarasov $\mathrm{VV}$, Aliev G. Is VEGF a key target of cotinine and other potential therapies against Alzheimer disease? Curr Alzheimer Res. 2017; 14:1155-63.

117. Minami T, Horiuchi K, Miura M, Abid MR, Takabe W, Noguchi N, Kohro T, Ge X, Aburatani H, Hamakubo T, Kodama T, Aird WC. Vascular endothelial growth factorand thrombin-induced termination factor, Down syndrome critical region-1, attenuates endothelial cell proliferation and angiogenesis. J Biol Chem. 2004; 279: 50537-54.

118. Yao YG, Duh EJ. VEGF selectively induces Down syndrome critical region 1 gene expression in endothelial cells: a mechanism for feedback regulation of angiogenesis? Biochem Biophys Res Commun. 2004; 321: 648-56.

119. Fujiwara M, Hasebe T, Kajita M, Ishizuya-Oka A, Ghazizadeh M, Kawanami O. RCAN1 regulates vascular branching during Xenopus laevis angiogenesis. J Vasc Res. 2011; 48: 104-18.

120. Ryeom S, Baek KH, Rioth MJ, Lynch RC, Zaslavsky A, Birsner A, Yoon SS, McKeon F. Targeted deletion of the calcineurin inhibitor DSCR1 suppresses tumor growth. Cancer Cell. 2008; 13: 420-31.
121. Kingsbury TJ, Cunningham KW. A conserved family of calcineurin regulators. Genes Dev. 2000; 14: 1595-604.

122. Lazarov O, Hollands C. Hippocampal neurogenesis: Learning to remember. Prog Neurobiol. 2016; 138-140: $1-18$.

123. Casas C, Martinez S, Pritchard MA, Fuentes JJ, Nadal M, Guimera J, Arbones M, Florez J, Soriano E, Estivill $\mathrm{X}$, Alcantara S. Dscr1, a novel endogenous inhibitor of calcineurin signaling, is expressed in the primitive ventricle of the heart and during neurogenesis. Mech Dev. 2001; 101: 289-92.

124. Li Y, Wang J, Zhou Y, Li D, Xiong ZQ. Rcan1 deficiency impairs neuronal migration and causes periventricular heterotopia. J Neurosci. 2015; 35: 610-20.

125. Wang W, Rai A, Hur EM, Smilansky Z, Chang KT, Min KT. DSCR1 is required for both axonal growth cone extension and steering. J Cell Biol. 2016; 213: 451-62.

126. Martin KR, Corlett A, Dubach D, Mustafa T, Coleman HA, Parkington HC, Merson TD, Bourne JA, Porta S, Arbones ML, Finkelstein DI, Pritchard MA. Over-expression of RCAN1 causes Down syndrome-like hippocampal deficits that alter learning and memory. Hum Mol Genet. 2012; 21: 3025-41.

127. Wang C, Saji M, Justiniano SE, Yusof AM, Zhang X, Yu L, Fernandez S, Wakely P Jr, La Perle K, Nakanishi H, Pohlman N, Ringel MD. RCAN1-4 is a thyroid cancer growth and metastasis suppressor. JCI Insight. 2017; 2: e90651.

128. Sales KJ, Maldonado-Perez D, Grant V, Catalano RD, Wilson MR, Brown P, Williams AR, Anderson RA, Thompson EA, Jabbour HN. Prostaglandin F(2alpha)F-prostanoid receptor regulates CXCL8 expression in endometrial adenocarcinoma cells via the calciumcalcineurin-NFAT pathway. Biochim Biophys Acta. 2009; 1793: 1917-28.

129. Lee HJ, Kim YS, Sato Y, Cho YJ. RCAN1-4 knockdown attenuates cell growth through the inhibition of Ras signaling. FEBS Lett. 2009; 583: 2557-64.

130. Ermak G, Harris CD, Davies KJ. The DSCR1 (Adapt78) isoform 1 protein calcipressin 1 inhibits calcineurin and protects against acute calcium-mediated stress damage, including transient oxidative stress. FASEB J. 2002; 16: 814-24.

131. Bhoiwala DL, Kannabiran V, Hushmendy SF, Hahn A, Heuring JM, Crawford DR. The calcineurin inhibitor RCAN1 is involved in cultured macrophage and in vivo immune response. FEMS Immunol Med Microbiol. 2011; 61: 103-13.

132. Martin KR, Layton D, Seach N, Corlett A, Barallobre MJ, Arbones ML, Boyd RL, Scott B, Pritchard MA. Upregulation of RCAN1 causes Down syndrome-like immune dysfunction. J Med Genet. 2013; 50: 444-54.

133. Vega RB, Yang J, Rothermel BA, Bassel-Duby R, Williams RS. Multiple domains of MCIP1 contribute to inhibition of 
calcineurin activity. J Biol Chem. 2002; 277: 30401-7.

134. Genesca L, Aubareda A, Fuentes JJ, Estivill X, De La Luna S, Perez-Riba M. Phosphorylation of calcipressin 1 increases its ability to inhibit calcineurin and decreases calcipressin half-life. Biochem J. 2003; 374: 567-75.

135. Ryeom S, Greenwald RJ, Sharpe AH, McKeon F. The threshold pattern of calcineurin-dependent gene expression is altered by loss of the endogenous inhibitor calcipressin. Nat Immunol. 2003; 4: 874-81.

136. Chan B, Greenan G, McKeon F, Ellenberger $T$. Identification of a peptide fragment of DSCR1 that competitively inhibits calcineurin activity in vitro and in vivo. Proc Natl Acad Sci U S A. 2005; 102: 13075-80.

137. Vega RB, Rothermel BA, Weinheimer CJ, Kovacs A, Naseem RH, Bassel-Duby R, Williams RS, Olson EN. Dual roles of modulatory calcineurin-interacting protein 1 in cardiac hypertrophy. Proc Natl Acad Sci U S A. 2003; 100: 669-74.
138. Aubareda A, Mulero MC, Perez-Riba M. Functional characterization of the calcipressin 1 motif that suppresses calcineurin-mediated NFAT-dependent cytokine gene expression in human T cells. Cell Signal. 2006; 18: 1430-8.

139. Porta S, Serra SA, Huch M, Valverde MA, Llorens F, Estivill X, Arbones ML, Marti E. RCAN1 (DSCR1) increases neuronal susceptibility to oxidative stress: a potential pathogenic process in neurodegeneration. Hum Mol Genet. 2007; 16: 1039-50.

140. Kim YS, Lee HJ, Jang C, Kim HS, Cho YJ. Knockdown of RCAN1.4 Increases Susceptibility to FAS-mediated and DNA-damage-induced Apoptosis by Upregulation of p53 Expression. Korean J Physiol Pharmacol. 2009; 13: 483-9. 